\title{
Muslims, Their Beliefs and Practices
}

\author{
A. Rippin.
}

New York: Routledge, 20()1. 346 pages.

Muslims, Their Beliefs and Practices is the revised 2nd edition of a previous work with the same title divided in two volumes: Vol. I, "The Formative 
Period," published in 1990, and vol. II, "Contemporary Period," which appeared in 1993. The present issue, like the preceding one, is a synthesis of the development of Islam throughout its history, from the 7th to the 20th century, with an insight into the challenges of the future. The author makes a review of Muslims' perceptions of their religion as well as the scholarly activity - by Muslims and non Muslims - dedicated to it. This critical attitude distinguishes the book from other introductions to Islam. According to its bibliography, the book is addressed to an audience deemed reluctant as regards to languages other than English. Yet the style and content of the book make of it a complicated reading for a lay public who tries a first approach to Islam.

Muslims, Their Beliefs and Practices is organized in six parts, each one introduced by a list of the most significant dates for the subject matter in question. Practical examples excerpted from the sources or the author's personal experience are used to illustrate his arguments. Notes appear at the end. Subsequently, the reader is provided with a glossary, a bibliography additional to that mentioned in the notes, a list of websites of use for students of Islam, a thematic index and finally, an index of Qur'anic citations.

Part I, "Formative Elements of Classical Islam," contains three chapters. Chapter 1, "Prehistory", covers the 6th century, a period in the history of Arabia on which research about the constituent elements of the new religion has focused. For his part, Rippin puts forward a gradual process from the 6th to the 8th centuries in the broader spatial context of the Near East as a more suitable model to understand the emergence of Islam. In Chapter 2, "The Qur'an," the author describes its form and content. Going further, he poses the questions of how, why and when the Qur'an became a text with the aspect it has today. Chapter 3, "Muhammad," discusses the problems of the historicity of the Prophet's biography as well as its significance.

Part II, "The Emergence of Islamic Identity," includes four chapters. Chapter 4, "Political action and theory," turns around three subjects: (a) the role of religion in the territorial expansion of the Arabs, (b) the role of politics in the enunciation of the classical form of Islam, and (c) the final separation between both the religious and the political spheres with the emergence of the class of the religious scholars (ulama). The latter assumed the formulation of Islamic faith and law: a process analyzed in chapters 5, "Theological Exposition," and 6, "Legal Developments," respectively. His treatment of these aspects appears rather influenced by the writings of P. Crone, M. Hinds and N. Calder. Chapter 7 is dedicated to the description and interpretation of Islam's external face: "Ritual Practice." 
Part III, "Alternative Visions of Islam," contains chapter 8, "The Shiza", and chapter 9, "Sufi devotion." Rippin underlines the symbolic value of the differences between Shis and Sunnis and their political functionality. With respect to Sufis, the author concludes that they have represented more than an alternative, a supplement, to the Islamic way of life.

In Part IV, "Consolidation of Islamic Identity," the constant re-elaboration of the literary tradition of Islam is presented as an effort to respond to the reality that has also led to the consolidation of an Islamic identity. Chapter 10, "Intellectual culture," addresses the non-religious sciences in the classical period. Chapter 11, "Medieval Visions of Islam," covers the process of reinterpretation of Islamic traditional disciplines in the post-classical period (13th-18th centuries).

Part V, "Modern Visions of Islam," is the longest part of the book. It is distributed in four chapters: chapter 12, "Describing Modernity," focuses on the impact of western colonization of Muslim lands. Rippin also insists on the need to pay attention to Islam's internal dynamics, and situates the definitions of modernity, post-modernity and tradition in the Islamic context. How have Muslims responded to the challenges of modernity? By means of a recreation of the figure of Muhammad, a question analyzed in chapter 13, "Muhammad and Modernity." Also by means of a constant reinterpretation of the Qur'an, illustrated in chapter 14, "The Qur'an and Modernity." In chapter 15, "Issues of Identity," the significance of the Islamic identity nowadays as well as the evolution experienced in its defining elements is examined. In this area, Rippin sees a tendency towards a "personalization of the faith" in which the ritual practices have been given a new meaning.

Part VI, "Revisioning Islam," contains chapters 16 "Feminism's Islam" and 17, "Visions for Islam in the Twenty-first Century and Beyond". Chapter 16 addresses Islam's response to change in the traditional family structure and the role of women in society. Chapter 17 is an attempt to outline the main challenges that Islam will have to face in the 21 st century, challenges which, this time, are posed by dissenting voices from inside the Muslim community. What the future generations of Muslims will make of this potential, concludes Rippin, is uncertain. Finally, he points to the convenience of seeing Islam, like other religions, "on a continuum, attempting self-conscious definition at times and reaching into the experiential dimension of religion in order to refresh those definitions at other times."

The preceding sketch can hardly do justice to the content of a work so rich and suggestive as Rippin's. His is a highly commendable book, which combines the effort to synthesize a complex and vast phenomenon like 
Islam with sharp criticism and a projection into the future. All works of synthesis have shortcomings, however: not all the facts that we judge as relevant are included; and bibliographical references are not always those we would have expected. This was particularly evident for me as regards Islamic law: Rippin has not followed the results of recent studies on the subject; his treatment of the subject, "the application of Islamic law in the Middle ages," is obsolete.

To these "natural" and somehow unavoidable limitations I would like to add the following remarks:

In his foreword, Rippin declares his intention to concentrate on the Arab-Persian Empire to study the classical period of Islam, in the Near East, the Indian subcontinent, Malaysia, North America and Europe for the modern period. Yet this focus responds more to the training and interests of the author than the fact that the most important events might actually have taken place in those geographical areas. As a consequence of this method, Islam is portrayed as the receptor of a variety of external influences, while the influences it exerted over other religions are ignored.

To be precise, I am referring to the process operated through the Muslim West by means of which the Islamized Greek thought passed to Europe, affecting not only scientific and philosophical knowledge but also theological speculation. In this connection, the name of the physician, philosopher, theologian and jurist Averroes can in no way be omitted. This omission is all the more surprising when we see that Rippin has taken into account other prominent Andalusian figures such as the Zahiri jurist, Ibn Hazm, and the Sufi, Ibn al- Arabi. The existence of "Purification Movements" is traced back to Ibn Taymiyya (13th century). However we have examples of much earlier manifestations of this tendency with the Almoravids (last quarter of the 11th century) and the Almohads (second half of 12th century).

Another negative consequence of Rippin's delimitation of his subject appears in his treatment of Sufism. The movement is presented as if it had never entered the political scene before the 16th century. However, it is known that in the first half of the 12th century, the Sufi order known as the Muridun, led by Ibn Qasi, seized power against the Almoravids in the western region of al-Andalus. Moreover, Rippin refers to the use that some Islamists made of the figure of the Hanbalite Damascene Jurist, Ibn Taymiyya, while he silences some modernists' resource to the Malikite Granadan jurist al-Shatibi.

The term mufti, legal expert who issues non-binding advisory opinions, is erroneously rendered as judge. My final comment relates to the discussion 
on the fabrication of prophetic traditions. According to I. Goldziher, J. Schacht and G.H.A. Juynboll, these reports were a late artificial elaboration gradually projected back to the Prophet's era. These opinions appear to be still admitted by a majority of scholars. However, I have missed some reference to W. Hallaq, H. Motzki, D. Powers, and U. Rubin, who have recently questioned them.

Delfina Serrano Ruano C.S.I.C. Instituto de Filologia, Departamento de Estudios Arabes Madrid, Spain 